\title{
Does It Matter If Statistical Agencies Frame the Month's CPI Report on a 1-Month or 12-Month Basis? Faculty Research Working Paper Series
}

\author{
Jeffrey Frankel
}

Harvard Kennedy School

Ayako Saiki

De Nederlandsche Bank

March 2016

RWP16-011

The views expressed in the HKS Faculty Research Working Paper Series are those of the author(s) and do not necessarily reflect those of the J ohn F. Kennedy School of Government or of Harvard University. Faculty Research Working Papers have not undergone formal review and approval. Such papers are included in this series to elicit feedback and to encourage debate on important public policy challenges. Copyright belongs to the author(s). Papers may be downloaded for personal use only. 


\title{
Does It Matter If Statistical Agencies Frame the Month's CPI Report on a 1-Month or 12-month Basis?
}

\author{
Jeffrey Frankel (Harvard University) and Ayako Saiki (De Nederlandsche Bank ${ }^{1}$ ) \\ The authors would like to thank Katharine Abraham and Richard Thaler for useful comments.
}

\begin{abstract}
When the US Bureau of Labor Statistics releases new numbers, in theory it should make no difference whether the press release emphasizes the most recent 1-month number, which is what it does, or the 12-month number, as many other countries' statistical agencies do. This paper offers the hypothesis that it does matter: Markets react to $\mathrm{CPI}$ inflation news via whichever framing the agency chooses.
\end{abstract}

JEL classification numbers: $E, F, G$

Key words: announcement, bond, $\mathrm{CPI}$, framing, inflation, market, monthly, reaction, release, statistical.

Official statistical agencies report GDP numbers every quarter and industrial production, inflation, and various employment measures every month. The complete statistical report that is released and posted on agency websites contains a lot of information. But in the United States, the agency's website and the headline and/or lead sentence of the agency's press release clearly and consistently emphasize the figure for the most recent period: the most recent quarter for the rate of growth in GDP and the most recent month for the CPI, Industrial Production, or employment (change from the previous month). In many other countries, the website and the headline or lead sentence of the press release emphasize instead the change over the preceding one-year interval - such as Canada and most European countries for CPI inflation, China and Taiwan for the GDP growth rate, Switzerland for industrial production, or Japan and Korea for change in employment. ${ }^{2}$

Economists' logic would say that it cannot make any difference what the agency chooses to emphasize in the website or press release that it gives to reporters and the public, so long as all the information is made available at the same time (including the estimate for the most recent period, revised numbers for one or more preceding periods, and the number for the preceding 12-months or 4 quarters). A standard criterion for the efficiency of financial markets is that they process all available government statistics. But the hypothesis explored in this paper is that it does make a difference, that

\footnotetext{
${ }^{1}$ The views expressed here are solely the ones of authors and do not necessarily reflect the views of De Nederlandsche Bank (the Dutch central bank, DNB). The authors would like to thank Zion Gorgi (DNB) and Martin Admiraal (DNB) for valuable help.

${ }^{2}$ There are also other systematic differences in the way that governments report statistics in different countries. In the United States, quarterly GDP growth rates are multiplied by four to express them at annual rates. Europeans and others do not multiply by four. The US Bureau of Labor Statistics (BLS), on the other hand, does not multiply the percentage change in the CPI or PPI by 12 in its press releases; as a result, inflation news reports usually headline an uninformative $0.1 \%$ number, for everything between $0.6 \%$ p.a. and $1.8 \%$ p.a. (i.e., between $0.05 \%$ and $0.15 \%$ per month). There are also international reporting differences with respect to headline versus core, seasonally adjusted versus not, etc. This paper is concerned only with the question of whether the releases emphasize the most recent period or the last year.
} 
financial markets tend to react relatively more strongly to the most recent number in countries such as the United States and to react relatively more strongly to the 12-month number in countries where that is the one emphasized in the press release.

Macroeconomists steeped in the literature on statistical effects of government adjustments may find the proposed outlook unfamiliar. ${ }^{3}$ The hypothesis will be less surprising to those familiar with the evidence on psychological biases of framing and anchoring. ${ }^{4}$ It may also be less surprising to market traders themselves, who do not feel they have the time to read the entire statistical release before rushing to participate in the market reaction. Given that the United States is the country that seems consistently to emphasize the most recent period in its statistical releases, the hypothesis considered here may also be of interest to those who believe that US financial markets suffer from "shorttermism." ${ }^{5}$

Others have noted possible evidence of over-reaction to short-term noise, for example the fact that markets react strongly to the preliminary estimate of GDP but not to subsequent revisions. Welltargeted tests are hard to construct, however. ${ }^{6}$

\section{Reporting practices in different countries}

Table 1 shows the CPI reporting practices of different countries, as between most-recent-period versus 12-month change, and the corresponding reporting tendencies across countries of the important financial wire services (Bloomberg and Reuters). The United States is the country where the news clearly and consistently focuses on CPI inflation for the most recent month. The statistical agencies in

\footnotetext{
${ }^{3}$ The necessary mental adjustment is perhaps analogous to what was needed 30 years ago to get macroeconomists interested in real-time government announcement effects in the first place. Some reactions were along the lines "why should we be interested in original announcements in dusty archives, when we have the correct revised numbers?" [A particular version of the rational expectations hypothesis had in effect held that economic agents intuit the true state of the economy, so that real time releases regarding economic statistics subject to subsequent revision would not be of interest.]

${ }^{4}$ E.g., Kahneman and Tversky (1984), Benartzi and Thaler (1995), De Bondt and Thaler (1996), Thaler, Tversky, Kahneman, and Schwartz (1997), Daniel, Hirshleifer, and Subrahmanyam (1998), Barberis, Shleifer, and Vishny (1998), Barberis, Huang, and Santos (2001), Daniel, Hirshleifer, and Teoh (2002), Barberis and Thaler (2003), and Thaler (2005), among others.

${ }^{5}$ E.g., Bolton, Scheinkman and Xiong (2006) and Froot, Scharfstein and Stein (1992).

${ }^{6}$ Bartolini, Goldberg and Sacarny (2008) are among those noting that the markets react to the advanced estimate of GDP but not noticeably to the revisions. This is important because Mankiw and Shapiro (1986), Faust, Rogers and Wright (2005), and others have documented that changes from the US flash estimate to preliminary, and from preliminary to revised, are usually large in magnitude. The market reactions don't necessarily prove irrationality or over-reaction, however, because the incremental value in each of the revisions might still be too small, when the first advanced number (even though highly imperfect) is already known. But it is highly suggestive that the Bureau of Economic Analysis stopped altogether reporting the preliminary flash estimate after 1985 (http://www.bea.gov/scb/account_articles/national/1093od/box1.htm). Whatever useful information there had been in the early estimate was apparently considered to be of less value than the danger that the public would read too much into a measure that BEA considered very noisy.
} 
Korea also give it emphasis. Correspondingly, the news services Bloomberg/World Process and Reuters tend to give greater emphasis to the month's number from the US, and somewhat less to the 12-month inflation rate. Most other countries do this differently. Canada and most European countries emphasize CPI changes on a 12-month basis in the official statistical reports. Bloomberg and Reuters follow suit in most of these countries.

\section{Table 1: Reporting patterns for CPI statistics released by official agencies and financial news services across countries}

\begin{tabular}{|c|c|c|c|c|}
\hline & \multicolumn{4}{|l|}{ Updated Sep 19, 2014} \\
\hline & Countries and release agencies & Gov't agency & Bloomberg & Reuters \\
\hline \multirow[t]{4}{*}{ Americas } & United States (BLS) & 5 & 5 & 3 \\
\hline & Canada (Stat Canada) & 1 & 1 & 1 \\
\hline & Mexico (National Statistic Institution) & 2 & 3 & 3 \\
\hline & Brazil (Central Bank) & 3 & 3 & 3 \\
\hline \multirow{9}{*}{ Eurozone } & Belgium (Directorate-general Statistics) & 5 & 2 & 2 \\
\hline & Finland (Stat Finland) & 1 & 2 & 1 \\
\hline & France (INSEE) & 2 & 1 & 3 \\
\hline & Germany (Statistisches Bundesamt) & 1 & 1 & 1 \\
\hline & Ireland (Central Statistics Office) & 2 & 1 & 1 \\
\hline & Italy (Istituto Nazionale di Statistica) & 4 & 1 & 1 \\
\hline & NL (Centraal Bureau voor de Statistiek) & 1 & 1 & 1 \\
\hline & Spain (Instituto Nacional de Estadistica) & 2 & 1 & 1 \\
\hline & Eurozone (Eurostat) & 1 & 1 & 1 \\
\hline \multirow{4}{*}{$\begin{array}{l}\text { Non-EZ } \\
\text { Europe }\end{array}$} & Denmark (Denmark Statistik) & 1 & 1 & 1 \\
\hline & Sweden (Statistics Sweden) & 1 & $3^{*}$ & $3^{*}$ \\
\hline & UK (Office for National Statistics) & 1 & 1 & 1 \\
\hline & Switzerland (Swiss Statistics) & 5 & 1 & 3 \\
\hline \multirow[t]{2}{*}{ Asia } & Japan (Stat Bureau) & 3 & 1 & 1 \\
\hline & Korea (Korea Statistics) & 5 & $3+$ & $3+$ \\
\hline
\end{tabular}

* English-language media tend to focus on MoM, while the local news services focus on YoY, consistent with the gov't release.

tEnglish media tend to focus on YoY, while the local news services focus on MoM, consistent with the government release.

$1=$ Emphasis (e.g., headlines) is clearly and consistently on the 12-month version, even though the monthly basis is also contained somewhere in the announcement.

2 = Some emphasis on the 12-month version, but not consistently, relative to the shorter-term basis.

$3=$ Precisely equal emphasis on both versions.

4= Some emphasis on the shorter term basis, but not consistently, relative to the 12-month basis.

5 = Emphasis (e.g., headline or first sentence) is clearly and consistently on the monthly (or quarterly) version, even though the 12-month basis is also contained in the announcement.

Note: Each country reports monthly, except for Denmark which reports quarterly.

Source: The Secrets of Economic Indicators and authors' investigations from press releases and news services. An appendix available online documents the basis of the classification of each country. 
Appendix Tables $1 \mathrm{~A}$ and $1 \mathrm{~B}$ report the corresponding information for GDP and employment reporting practices. For GDP growth, the US has a lot more company in its short-termism. A majority of countries, including the UK, Canada, Japan, and the Eurozone, emphasize growth in the most recent quarter. The news outlets tend to do the same for these countries, reporting the most recent quarter. China and Taiwan, on the other hand, report GDP growth with an emphasis on the 4-quarter basis. In these two countries the media outlets again follow suit (Bloomberg and Reuters). ${ }^{7}$

\section{Reactions in bond markets}

Statistical findings of highly significant positive jumps in interest rates in response to inflationary news go back to the early 1980s, when Fed money announcements were important: Grossman (1981), Roley (1983), Urich and Wachtel (1981), Urich (1982), Naylor (1982), Cornell (1982), Engel and Frankel $(1982,1984)$, and Campbell et al. (1983). More recent papers, able to take advantage of larger and higher-frequency data sets, have similarly found interest rates rising or bond prices falling in reaction to news of higher inflation or stronger economic growth. They include Fleming and Remolona (1999), Gurkaynak, Sack and Swanson (2005), Andersen et al. (2007), Faust et al. (2007), Goldberg and Leonard (2003), and Ehrmann and Fratscher (2005), among others.

We now examine the patterns of reaction in the bond markets of different countries. In this preliminary study, we focus on the effects of CPI announcements on the one-day change in 10-year bond prices, comparing them before and after the announcement. One could also look at the reactions in stock markets and foreign exchange markets. ${ }^{8}$ But theory is ambiguous as to the predicted direction of reaction in those two markets: on the one hand, higher inflation itself should be bad news for the foreign exchange value of the domestic currency but, on the other hand, the likelihood that the monetary authority will react to the news by tightening is good news for the value of the currency. The same ambiguity applies to stock market reactions.

We could also look at the financial market reactions to official announcements of GDP, employment, or other measures of economic activity. But, again, there is a theoretical ambiguity. To the extent that news of strong growth raises interest rates, it should have a negative effect on bond prices, stock prices, and the exchange rate (price of foreign currency). But in each case there are also effects that go the other way (respectively: default risk, earnings growth, and the demand for money). Sure enough others' studies of the effect of inflation and other economic announcements tend to find weaker effects on equity and foreign exchange markets than on bond markets and to explain this in terms of the ambiguous theoretical effect. To quote Bartolini, Goldberg and Sacarny (2008, p.2): “...the strongest effects are seen on interest-bearing assets... The effects of economic news on stock prices are

\footnotetext{
${ }^{7}$ Baum, Kurov, and Wolfe (2015) find that announcements of GDP and 11 other Chinese variables move stock markets worldwide.

${ }^{8}$ E.g., Andersen, Bollerslev, Diebold and Vega (2007), Evans and Lyons (2005), Galati and Ho (2003), and Love and Payne (2008). It is a large literature. Studies of short-term reactions to monetary releases, for example, go back at least to Pearce and Roley $(1985)$ in the stock market and to Engel and Frankel $(1982,1984)$ in the foreign exchange market. Neely and Dey (2010) survey the latter literature.
} 
harder to predict...The consequences of economic news for exchange rates are also somewhat ambiguous."

Table 2 reports regressions of the reactions to CPI releases of prices of 10 -year bonds in four countries (\% change of 10 year government bond price). The new CPI number is expressed as the difference from the forecast made immediately before the release. The forecast is measured as the average of analysts' forecasts compiled by Bloomberg. In line with much research on announcement effects ("news" or "event studies"), what should matter is the announcement relative to what the market had been expecting. The first right-hand side variable is the newly released CPI number for the most recent month. The other variable is the newly released inflation rate over the preceding $12-$ months.

The first regression, in column 1, applies to data from two countries that emphasize the 12month inflation rate in the headlines of their press releases: Canada and the United Kingdom. The second regression, in column 2, applies to data from two countries that give more emphasis to the most recent month's CPI inflation: the US and Korea. Recall that all these countries make all the information available, both 1-month and 12-month; we are distinguishing the countries according to the headline habits of the statistical agencies in their press releases.

Table 2 Reactions to CPI releases in countries that emphasize 12-month vs. 1-month news Panel regression (with country fixed effects)

\begin{tabular}{|c|c|c|}
\hline \multicolumn{3}{|c|}{$\begin{array}{l}\text { Dependent Variable: \% change in } 10 \text { year government bond prices } \\
\text { (from the day before the announcement to the day following) }\end{array}$} \\
\hline $\begin{array}{r}\text { Emphasis of Inflation Announcement } \\
\text { Countries }\end{array}$ & $\begin{array}{c}\text { (1) } \\
\text { 12-month } \\
\text { UK and Canada }\end{array}$ & $\begin{array}{c}\text { (2) } \\
\text { Month-on-month } \\
\text { US and Korea }\end{array}$ \\
\hline $\begin{array}{l}\text { MoM Surprise }{ }^{\dagger} \\
\text { YoY Surprise }{ }^{\dagger} \\
\text { Constant }\end{array}$ & $\begin{array}{c}0.002 \\
{[1.09]} \\
-0.006^{* * *} \\
{[-2.76]} \\
-0.0003 \\
{[-1.28]} \\
\end{array}$ & $\begin{array}{c}-0.019 \\
{[-1.48]} \\
0.002 \\
{[1.46]} \\
0.0002 \\
{[0.61]} \\
\end{array}$ \\
\hline $\begin{array}{r}\text { Number of observations } \\
\mathrm{R}^{2} \\
\text { F-value } \\
\text { Prob }>\mathrm{F}\end{array}$ & $\begin{array}{c}267 \\
0.06 \\
7.4 \\
0.0007\end{array}$ & $\begin{array}{c}259 \\
0.01 \\
1.1 \\
0.33\end{array}$ \\
\hline
\end{tabular}

$* * *$ Statistically significant at $1 \%$ level. (t-statistics are in parentheses.)

+ Surprise $\equiv$ announcement minus forecast. Forecast is from average of analysts' forecasts of that number (MoM or YoY) before announcement. The source is Bloomberg.

Sample period (by month of release) Canada: February 2003 - August 2014

Korea: Feb 2004 - Dec 2013

UK: Dec 2003 - August 2014

US: February 2003 - August 2014 
This table offers some preliminary support for the hypothesis. In Canada and the UK the expected reaction - the bond market falls when inflation is higher than expected - comes entirely with respect to the 12-month number, which is the one that these authorities headline. The coefficient is negative and significant. But given that, they pay no attention to the month-on-month number; its coefficient is insignificant and the sign is wrong. In the US and Korea, the signs are the other way around: the negative reaction of bond markets to inflation news comes in the form of the reaction to the information about the latest month, though it misses being statistically significant.

We have also estimated the equation for each country individually (Appendix Table 2B). The findings are qualitatively similar. In the UK, it is again the 12-month number that has a statistically significant negative effect, with higher significance now that the country is considered on its own. But the significance of this coefficient in the case of Canada diminishes, compared to Table 2 where the data were grouped together with the UK. In the US and Korea it is again the month-on-month number that has the negative effect on bond prices, as hypothesized. The significance level goes up slightly for Korea and down slightly for the US, compared to Table 2 where the two were grouped together. The need for data that will allow a test with high power is evident. Recall that studies with intra-daily data have found highly significant reactions to the statistical releases; we are just trying to pin down whether the framing affects the reaction.

These results are preliminary. Further research could extend the tests to other statistical releases (measures of economic activity such as growth in GDP, industrial production, and employment) and to reactions in other markets (equities and foreign exchange).

The highest priority should be to obtain data observed at a higher frequency: over an hour or half-hour interval, before and after each announcement. So far we only have data observed from one day to the next. But we know from the existing literature that reactions that are strong over a short interval can get swallowed up over a one-day interval, because a lot of other things happen in the course of the day in addition to the statistical release. ${ }^{9}$ Bartolini, Goldberg and Sacarny (2008), for example, find that the size and significance of the effect diminishes as one moves from the half-hour reaction, to a mid-day observation, to end-of-trading day, let alone over a 24-hour window: "the immediate effect can generally be measured more precisely than the full-day impact" and "...the immediate effects of economic news on asset prices are easier to assess than the full-day effects, because the accumulation of other shocks to asset prices through the business day makes the identification of persistent effects more difficult." (p.5).

\footnotetext{
${ }^{9}$ Preliminary tests of GDP and employment releases, and reactions in other markets, have not yielded very edifying results so far. This may be because of the coarseness of the one-day interval. Or it may be because of the theoretical ambiguities mentioned above, which take hold when we move away from the effect of inflation announcements on bond prices.
} 


\section{Implications}

No doubt these results require qualification. One theoretical possibility is that the most recent observation could carry relatively more genuine information about the economy in some countries than in others, and the statistical agencies could tailor their reporting tendencies in response to this. ${ }^{10}$ But at this stage, the biggest qualification is that the data used here do not allow a sufficiently powerful test. The hypothesis needs to be tested more extensively, especially on higher-frequency data sets. It is also important to test the difference in impacts of GDP and Industrial Production announcements.

If the results in Table 2 do turn out to hold up, then the implications will be striking. As positive social science, the hypothesis is consistent with theories of framing and anchoring that come from psychology.

But it also implies a remarkably practical policy recommendation for the US Bureau of Labor Statistics and Bureau of Economic Analysis and other official statistical agencies around the world. The limited word space in a newspaper headline and limited cognitive space in human mental capacities are presumably the reasons for the observed tendency for agencies and news services to choose to focus on one measure above others: either the latest period or the 12-month average. Which focus is "best practice"? There are reasons to deem the one-year average more informative. It contains the information in the latest month or quarter and more beyond that. Even in a world of full rationality, the announcement of a 4-quarter average of GDP growth or a 12-month average of employment growth contains important new information in addition to the latest period's number: revisions in the preceding quarters or months, which are often substantial. Of course these revisions are available elsewhere in the statistical release. But the hypothesis, and the supporting evidence in Table 1, suggests that a single headline number receives far more attention than other numbers in the release.

In addition, once we admit the likelihood of departures from full rationality, we must recognize that even if figures from previous months or quarters have not been revised, they may fade from people's awareness more quickly than is rational. We must consider that a focus on the most recent month or quarter may lead financial market participants and others to put too much weight on highly noisy short-term numbers, and to lose sight of the more meaningful medium-term trend. A one-year average is an efficient way to convey the recent trend. That much of the information in it was already available in the previous period's announcement of the one-year trend at that time does not necessarily mean that observers do not need to be reminded of it, in order to gain a good fact-based perspective. A 12-month or 4-quarter change also carries the extra advantage of avoiding problems of seasonal adjustment, which can sometimes be problematic.

If government statistical announcements could be made more informative, that could have implications well beyond the financial markets studies in this paper. Firms' hiring and investment decisions depend on their perceptions of the current state of the economy. There is even evidence that such decisions may respond more to the initial GDP releases, for example, than to the "true" state of economic activity as captured by the final GDP numbers.

\footnotetext{
${ }^{10}$ This point was made to the author by Larry Summers.
} 
Making it easier for the public to gain perspective on the state of the economy could have benefits as well for the participation of ordinary citizens in the political process. It is possible that most people do not even bother to follow economic statistics because the short-term noise is so great in what they hear or read that there is not much value in trying. Polls indicate that $4 \frac{1}{2}$ years after the end of the great recession in mid-2009, from $74 \%$ to nearly 80 per cent of Americans thought that the country was still in recession. As of June 1, 2014, only 43 per cent thought that the U.S. economy had even begun to recover. One could give other examples of unawareness of economic statistics, from other stages in the business cycle (and from other presidents' terms). But what looks like ignorance may be a result of "rational inattention." ${ }^{11}$ If it were made easier for the public to get a genuine reading on the state of the economy, it might help them in their lives as individual decision-makers in the economy and as voters in a well-functioning democracy. ${ }^{12}$

\section{References}

Andersen, Torben, Tim Bollerslev, Francis Diebold, and Clara Vega (2007), "Real-Time Price Discovery in Global Stock, Bond and Foreign Exchange Markets," Journal of International Economics, 73(2), pp. 251 - 277.

Barberis, Nicholas, Ming Huang, and Tano Santos (2001), "Prospect Theory And Asset Prices," The Quarterly Journal of Economics, 116(1), pp.1-53.

Barberis, Nicholas, Andrei Shleifer, and Robert Vishny (1998), "A model of Investor Sentiment," Journal of Financial Economics 49(3), pp.307-343.

Barberis, Nicholas, and Richard Thaler (2003) , "A Survey of Behavioral Finance," in M. Constantinides \& M. Harris \& R. Stulz (ed.), Handbook of the Economics of Finance, Edition 1, volume 1, Chapter 18, pp. 1053-1128.

Bartolini, Leonardo, Linda Goldberg, and Adam Sacarny (2008), "How Economic News Moves Markets," Current Issues in Economics and Finance (Federal Reserve Bank of New York), 4(6).

Baum, Christopher F., Alexander Kurov, and Marketa Halova Wolfe (2015), "What do Chinese Macro Announcements Tell Us About the World Economy?" Journal of International Money and Finance 59, pp.100-122.

Baumohl, Bernard (2012), The Secrets of Economic Indicators: Hidden Clues to Future Economic Trends and Investment Opportunities (3rd Edition), FT Press.

Benartzi, Shlomo, and Richard Thaler (1995), "Myopic Loss Aversion and the Equity Premium Puzzle" Quarterly Journal of Economics, 110(1), February, pp. 73-92. Also NBER WP 4369.

Bolton, Patrick, José Scheinkman, and Wei Xiong (2006), "Executive Compensation and Short-Termist Behavior in Speculative Markets," Review of Economic Studies, 73(3), pp. 577-610.

Campbell, John, Kermit Schoenholtz and Robert Shiller (1983), "Forward Rates and Future Policy: Interpreting the Term Structure of Interest Rates," Brookings Papers on Economic Activity, 1, pp.173-217.

Cornell, Bradford (1982), "Money Supply Announcements, Interest Rates, and Foreign Exchange," Journal of International Money and Finance 1, pp. 201-208.

\footnotetext{
${ }^{11}$ E.g., Mankiw, Reis, and Wolfers (2003).

${ }^{12}$ Any change in procedure should be decided and announced during one president's term to take effect during the next.
} 
Daniel, Kent, David Hirshleifer, and Avanidhar Subrahmanyam (1998), "Investor Psychology and Security Market Under-and overreactions," The Journal of Finance 53(6), pp. 1839-1885.

Daniel, Kent, David Hirshleifer and Siew Hong Teoh (2002), "Investor Psychology in Capital Markets: Evidence and Policy Implications," Journal of Monetary Economics, 49(1), pp. 139-209.

De Bondt, Werner F.M, and Richard H Thaler (1996), "Financial Decision-making in Markets and Firms: A Behavioral Perspective," Handbook in Operations Research and Management Science, Vol. 9, Finance. Also NBER WP no. 4777.

Ehrmann, Michael, and Marcel Fratzscher (2005), "Equal Size, Equal Role? Interest Rate Interdependence between the Euro Area and the United States," Economic Journal, 115(506), pp. 930-950.

Engel, Charles, and Jeffrey Frankel (1982), "Why Money Announcements Move Interest Rates: an Answer From the Foreign Exchange Market," Proceedings, Federal Reserve Bank of San Francisco, Nov., pp.1-36. Also NBER WP 1049.

Engel, Charles, and Jeffrey Frankel (1984), "Why Interest Rates React to Money Announcements: An Explanation From the Foreign Exchange Market," Journal of Monetary Economics, 13(1), pp. 31-39.

Evans, Martin, and Richard Lyons (2005), "Do Currency Markets Absorb News Quickly?." Journal of International Money and Finance 24 (2), pp/ 197-217.

Faust, Jon, John Rogers, Shing-Yi Wang, and Jonathan Wright (2007), "The High-Frequency Response of Exchange Rates and Interest Rates to Macroeconomic Announcements," Journal of Monetary Economics 54(4) , pp. 1051-1068.

Faust, Jon, John Rogers, and Jonathan Wright (2005), "News and Noise in G-7 GDP Announcements," Journal of Money, Credit and Banking, 37(3), pp. 403-419.

Fleming, Michael, and Eli Remolona (1999), “Price Formation and Liquidity in the U.S. Treasury Market: The Response to Public Information," Journal of Finance, 54(5), pp. 1901-1915.

Froot, Kenneth, David Scharfstein, and Jeremy Stein (1992), "Herd on the Street: Informational Inefficiencies in a Market with Short-Term Speculation," The Journal of Finance, 47(4), pp.1461-1484.

Galati, Gabriele, and Corrinne Ho, 2003, "Macroeconomic News and the Euro/dollar Exchange Rate," Economic Notes 32(3), pp. 371-398.

Goldberg, Linda, and Deborah Leonard (2003), "What Moves Sovereign Bond Markets? The Effects of Economic News on U.S. and German Yields," Current Issues in Economics and Finance, no.9 (Federal Reserve Bank of New York),

Grossman, Jakob (1981), "The 'Rationality' of Money Supply Expectations and the Short-Run Response of Interest Rates to Monetary Surprises," Journal of Money, Credit, and Banking, 13, pp. 409-424.

Gurkaynak, Refet, Brian Sack, and Eric Swanson (2005), "The Sensitivity of Long-Term Interest Rates to Economic News: Evidence and Implications for Macroeconomic Models," American Economic Review 95(1), pp. 425-436.

Kahneman, Daniel, and Amos Tversky (1984), "Choices, Values, and Frames," American Psychologist 39(4), pp.341-350.

Love, Ryan, and Richard Payne (2008), "Macroeconomic News, Order Flows, and Exchange Rates," Journal of Financial and Quantitative Analysis (Cambridge University Press), vol. 43(02), pp.467-488, June.

Mankiw, N. Gregory; Ricardo Reis, and Justin Wolfers (2003), "Disagreement About Inflation Expectations," NBER Macroeconomics Annual 2003, ed. by M. Gertler and K. Rogoff.

Mankiw, N. Gregory, and Matthew Shapiro (1986), "News or Noise: An Analysis of GNP Revisions," Survey of Current Business, 66, pp.20-25.

Mora, José V. Rodríguez, and Paul Schulstad (2007), "The Effect of GNP Announcements on Fluctuations of GNP Growth," European Economic Review 51.8, pp. 1922-1940. 
Naylor, John A (1982), “Do Short-Term Interest Rate Expectations Respond to New Information on Monetary Growth?" Southern Economic Journal, 48(3), pp. 754-763.

Neely, Christopher J., and S. Rubun Dey (2010), "A Survey of Announcement Effects on Foreign Exchange Returns." Federal Reserve Bank of St. Louis Review 92.5, pp.417-463.

Pearce, Douglas, and Vance Roley (1985), "Stock Prices and Economic News," The Journal of Business, University of Chicago Press, 58(1), pp. 49-67. Also NBER WP 958, 1982.

Rigobon, Roberto, and Brian Sack, 2008, "Noisy Macroeconomic Announcements, Monetary Policy, and asset prices." Asset Prices and Monetary Policy (University of Chicago Press), pp. 335-370.

Roley, Vance (1983), "The Response of Short-Term Interest Rates to Weekly Money Announcements," Journal of Money, Credit and Banking, 15(3), pp.344-354.

Thaler, Richard, ed., Advances in Behavioral Finance, Volume 2 (Princeton University Press).

Thaler, Richard, Amos Tversky, Daniel Kahneman, and Alan Schwartz (1997), "The Effect of Myopia and Loss Aversion on Risk Raking: An Experimental Test," The Quarterly Journal of Economics Vol. 112 (2), May, pp.647-661

Urich, Thomas, and Paul Wachtel (1981), "Market Response to the Weekly Money Supply Announcements in the 1970s," Journal of Finance, 36(5), pp.1063-1072.

Urich, Thomas (1982), "The Information Content of Weekly Money Supply Announcements," Journal of Monetary Economics, 10(1), pp.73-88. 
Appendix Table 1a: Reporting patterns for GDP and employment statistics released by official agencies and financial news services across countries

\begin{tabular}{|c|c|c|c|c|}
\hline \multicolumn{2}{|c|}{ GDP growth } & \multicolumn{3}{|c|}{$\begin{array}{l}\text { Focus of release } \\
\text { (see below for definition) }\end{array}$} \\
\hline & Country and Release Agency & $\begin{array}{c}\text { Government } \\
\text { agency } \\
\text { release }\end{array}$ & Bloomberg & Reuters \\
\hline \multirow{4}{*}{ America } & $\underline{\text { USA }(B L S)}$ & $5+$ & $5+$ & $5+$ \\
\hline & Canada (Stat Canada) & $5^{\#}$ & $5+$ & $5+$ \\
\hline & Mexico (INEIG) & 1 & 5 & 4 \\
\hline & Brazil (Statistics Portal Brazil) & 2 & 3 & 5 \\
\hline \multirow{9}{*}{ Eurozone } & Belgium (Bank of Belgium) & 1 & 5 & 4 \\
\hline & Finland (Stat Finland) & 2 & 5 & 4 \\
\hline & France (INSEE) & 5 & 5 & 5 \\
\hline & Germany (Statistisches Bundesamt) & 5 & 5 & 5 \\
\hline & $\underline{\text { Ireland (Central Statistics Office) }}$ & 5 & 5 & 5 \\
\hline & Italy (Istituto Nazionale di Statistica) & 4 & 5 & 5 \\
\hline & $\underline{\mathrm{NL} \text { (Centraal Bureau voor de Statistiek) }}$ & $4 *$ & 5 & 5 \\
\hline & $\underline{\text { Spain (Instituto Nacional de Estadistica) }}$ & 2 & 5 & 5 \\
\hline & Eurozone (Eurostat) & 5 & 5 & 5 \\
\hline \multirow{4}{*}{$\begin{array}{l}\text { Non-Euro } \\
\text { Europe }\end{array}$} & Denmark (Danmarks Statistik) & 5 & 5 & 4 \\
\hline & $\underline{\text { Sweden (Statistics Sweden) }}$ & 1 & 3 & 5 \\
\hline & $\underline{\text { UK (Office for National Statistics) }}$ & 4 & 5 & 4 \\
\hline & Swiss (Statistics Swiss) & 5 & 5 & 4 \\
\hline \multirow{4}{*}{ Asia } & Japan (Cabinet Office) & 5 & $5+$ & $5+$ \\
\hline & Korea (Bank of Korea) & 5 & 5 & 4 \\
\hline & China & 1 & 1 & 1 \\
\hline & Taiwan & 1 & 1 & 1 \\
\hline
\end{tabular}

Note regarding press statement accompanying release of statistics:

$1=$ Emphasis is clearly on the annual basis.

2 = Some emphasis on the annual version, but not consistently, relative to the shorter-term basis.

3 = Precisely equal emphasis on both versions.

4 = Some emphasis on the quarterly basis, but not consistently, relative to the 12-month basis.

$5=$ Emphasis is clearly and consistently on quarterly version.

An appendix available online documents the basis of the classification of each country.

+ Month-on-Month $\quad+$ Annualized Quarter-on-Quarter.

\# Canada also reports monthly growth figures as a reference.

* The Netherlands Statistics Bureau (CBS) recently changed its focus from annual to quarterly (in 2012). 
Appendix Table 1b Change in employment

\begin{tabular}{|l|l||c|cc|}
\hline \multirow{2}{*}{} & \multicolumn{1}{|c||}{} & \multicolumn{3}{c|}{ Focus of release } \\
\cline { 2 - 5 } & Definition & Government & Reuters & Bloomberg \\
\hline Canada & People in Employment & MoM & MoM & MoM \\
Japan & People at Work & YoY & N/A* & N/A \\
US & Payroll Non-Farm Employment & MoM & MoM & MoM \\
Korea & Number of Employed & YoY & N/A & N/A \\
\hline
\end{tabular}

*In Japan and Korea, the news services almost exclusively report the unemployment rates, not changes in employment.

Appendix Table 2B: Reactions to CPI releases by individual country

\begin{tabular}{|c|c|c|c|c|}
\hline \multicolumn{5}{|c|}{$\begin{array}{l}\text { Dependent Variable: \% change in } 10 \text { year government bond prices } \\
\text { the days before the announcement and the day following) }\end{array}$} \\
\hline Emphasis of Inflation Announcement & 12-mon & tion & Montr & nonth \\
\hline Country & Canada & UK & Korea & US \\
\hline MoM Surprise ${ }^{\dagger}$ & $\begin{array}{c}-0.0006 \\
{[-0.21]}\end{array}$ & $\begin{array}{c}0.01 \\
{[0.03]}\end{array}$ & $\begin{array}{l}-0.065 \\
{[-1.61]}\end{array}$ & $\begin{array}{c}-0.02 \\
{[-1.03]}\end{array}$ \\
\hline YoY Surprise $†$ & $\begin{array}{l}-0.002 \\
{[-0.70]}\end{array}$ & $\begin{array}{l}-0.02^{* * *} \\
{[-3.56]}\end{array}$ & $\begin{array}{l}0.005 \\
{[1.60]}\end{array}$ & $\begin{array}{l}0.001 \\
{[1.01]}\end{array}$ \\
\hline Constant & $\begin{array}{c}-0.0002 \\
{[-0.58]}\end{array}$ & $\begin{array}{l}-0.002 \\
{[0.57]} \\
\end{array}$ & $\begin{array}{c}-0.0006 \\
{[-1.37]}\end{array}$ & $\begin{array}{c}0.0008 \\
{[1.55]}\end{array}$ \\
\hline Number of observations & 139 & 128 & 120 & 139 \\
\hline $\mathrm{R}^{2}$ & 0.02 & 0.13 & 0.02 & 0.01 \\
\hline F-value & 1.28 & 6.66 & 1.3 & 0.59 \\
\hline Prob > F & 0.28 & 0.002 & 0.28 & 0.56 \\
\hline
\end{tabular}

\footnotetext{
*** Statistically significant at $1 \%$ level. $\quad$ (t-statistics are in parentheses.)

Regressions use heteroscedasticity-consistent standard errors.

† Surprise $\equiv$ announcement minus forecast. Forecast is from average of analysts' forecasts of that number (MoM or YoY) before announcement. The source is Bloomberg.
}

\section{Sample period (by month of release)}

Canada: February 2003 - August 2014

Korea: Feb 2004 - Dec 2013

UK: Dec 2003 - August 2014

US: February 2003 - August 2014 